TAPROBANICA, ISSN 1800-427X. April, 2013. Vol. 05, No. 01: pp. 73-74.

(C) Taprobanica Private Limited, 146, Kendalanda, Homagama, Sri Lanka.

www.taprobanica.org

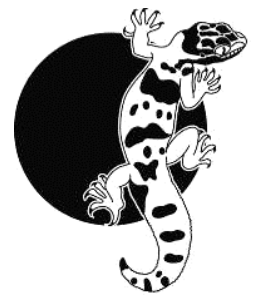

\section{Lyriothemis acigastra: a new addition to the odonata fauna of Peninsular India}

The exclusively old world genus Lyriothemis Brauer, 1868 (Anisoptera: Libellulidae), with 15 species (Schorr et al., 2012), is widespread across Asian countries occurring in Bangladesh, Tibet, North East India, Myanmar, Thailand, Nepal, Laos, Vietnam, Hong Kong, etc. Of these, L. acigastra (Selys, 1878), L. bivittata (Rambur, 1842), L. cleis (Brauer, 1868) and L. tricolor Ris, 1919 are so far known from India (Subramanian, 2009) of which all are restricted to Assam and West Bengal, the northeastern part of the country. Here we report this species from South India (Kerala). Based on a photograph of this species taken by the junior co-author, we conducted surveys to locate the specimens in the midland laterite hill areas of North Kerala. We found individuals (Fig. 1A, B) in Aravanchal and Madayipara areas in Kannur District of North Kerala during July to September, 2010.

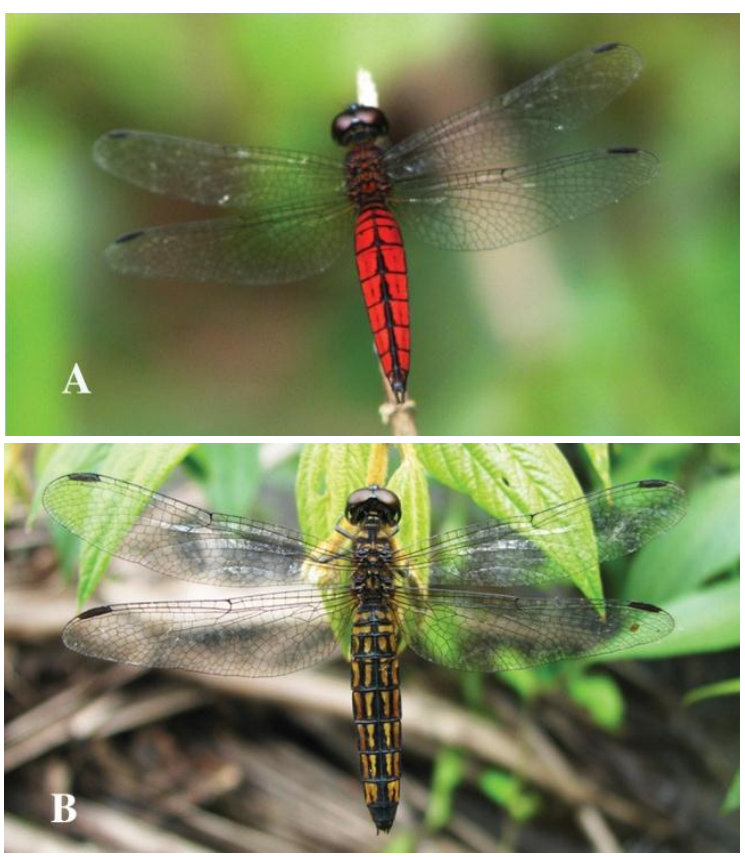

Figure 1: Lyriothemis acigastra, A, male; B, female (ZSI/WGRC/IR-I/od-302 and -303 respectively).
Specimens from north Kerala agree with those given by Fraser (1936) for this species. The secondary genitalia (Fig. 2) agree with Fraser's (1936) figure of L. acigastra.

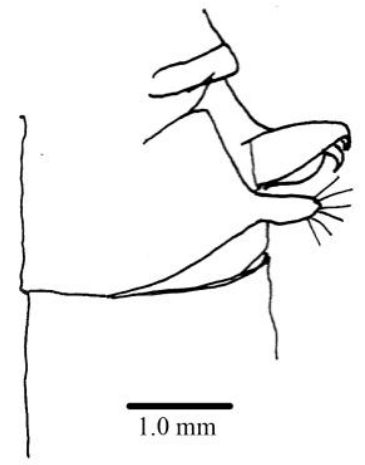

Figure 2: Secondary genitalia of L. acigastra.

Recent discovery of Lyriothemis defonsekai from Sri Lanka (Van der Poorten, 2009) points out a lack of knowledge of the distribution of this genus in the southern part of Indian subcontinent. It is unfortunate that Van der Poorten (2009) did not provide comparative illustrations of $L$. acigastra in her paper describing $L$. defonsekai. Van der Poorten (2009) compares $L$. defonsekai with $L$. acigastra mentioning a more pronounced anterior lamina for $L$. defonsekai which unfortunately, is not shown in her Figure - 2, and has differently shaped hamules. However, her illustration of the hamules of $L$. defonsekai, approximates that of L. acigastra given by Fraser (1936: 266, Fig. 81a) closely. One wonders if the arcuate line immediately posterior to the hamule she gives for $L$. defonsekai, might represent the outline of the base of the vesica spermalis. The present report of $L$. acigastra from north Kerala is therefore intriguing.

Specimens examined: Aravanchalkavu, Kannur District: ZSI/WGRC/IR-I/od-302; male (Abdomen: $20.0 \mathrm{~mm}$; hindwing: $25.0 \mathrm{~mm}$ ), Madayipara, Kannur district: ZSI/WGRC/IRI/od-303; female (Abdomen: 21.0mm; hindwing: $27.0 \mathrm{~mm}$ ); Muhamed Jafer Palot. 
Our specimen varies from Fraser's (1936) description by the following characters: Male: Labrum yellow with shining black border; border of anterior lobe of prothorax yellow; underside of thorax black with yellow stripe at the middle; all coxae and trochanters of legs yellow. Wings: in one specimen, subtrigone in right forewing entire, that of left forewing traversed; in second specimen, right discoidal cell and subtrigone in forewing entire, whereas the left discoidal cell traversed; Fw antenodals $9-11$, postnodals $7-8$; Hw antenodals $8-10$, postnodals 6-8. Abdomen: underside black with irregular yellow blotches from segments 1 to 8 . Female: Thorax yellow, black markings as in male, yellow colour brighter than in male. Fw antenodals 12, postnodals 8; Hw antenodals 9-10, postnodals $8-9$.

Even though the species is reported from other areas of the world, there is no information available on its ecology and habitat. This may be due to its secretive nature and rare occurrence. The general habitat of the species includes bushes associated with freshwater streams and marshes. Most of the males were collected from the marshy area adjoining the Aravanchal sacred grove, frequenting the shades of bushes, whereas the females were seen mainly near the fast flowing stream. The perennial rocky stream at Aravanchal is entirely covered with aquatic plants like Eriocaulon setacea and Crinum coromandelicum. The stream edges are lined with Syzigium caryophyllifolium, Leea indica, Memycylon grandis, etc. We had observed a small population of about 2-12 numbers during our visits. A freshly emerged female was also sighted on 19 September 2010. A total of 10 males and two females were sighted during a single day on 8 August 2010 from Aravanchalkavu. The dragonflies were active mainly during evening and morning hours. Most of the males were seen resting at a height of $8-10 \mathrm{~m}$ from the ground and also predating on the small moths and hesperiid butterflies.

A female was collected from Madayipara on 9 September 2010, on the southwestern slopes of the hill from a thicket dominated by Acacia instia and Ziziphus rugosa. Subsequently two more females were also sighted on the hill slopes on 21 September 2010.
During our subsequent visits in October and early November, no Lyriothemis was noticed at Madayipara and Aravanchalkavu. Though the Madayipara site has been monitored for last ten years for entomofauna, we had never encountered this species from the locality in the past indicating that, the species is probably a breeding visitor during the southwest monsoon in July- September or a recent colonist from elsewhere. Both these sites are located on the midland laterite hillocks associated with freshwater perennial streams or marshes nearby.

\section{Acknowledgements}

We are grateful to the Director (ZSI) for facilities and encouragement, Nancy Van Der Poorten for valuable suggestions and translating the original description. Dennis Paulson (USA), John Abbott (University of Texas, USA) and Rosser Garrison (CDFA USA) for editing and reviewing the manuscript.

\section{Literature cited}

Fraser, F. C., 1936. The Fauna of British India, including Ceylon and Burma: Odonata, Vol. 3. Taylor \& Francis Ltd., London: 461.

Schorr, M., M. Lindeboom and D. Paulson, 2012. $<$ http://www.pugetsound.edu/academics/academi c-resources/slater-museum/biodiversityresources /dragonflies/world-odonata-list/>

Subramanian, K. A. 2009. A checklist of Odonata (Arthropoda: Insecta) of India. Zoological Survey of India, Kolkata <http://zsi.gov.in/checklist/ Odonata_Indica_151209.pdf>

Van der Poorten, N. 2009. Lyriothemis defonsekai spec. nov. from Sri Lanka with a review of the known species of the genus (Anisoptera: Libellulidae). Odonatologica, 38 (1): 15-27.

Submitted: 14 June 2012, Accepted: 28 Nov. 2012 Sectional Editor: Rosser Garrison

K. G. Emiliyamma ${ }^{1,3}$, Md. Jafer Palot ${ }^{1}$, C. Radhakrishnan ${ }^{1} \&$ V. C. Balakrishnan ${ }^{2}$

${ }^{1}$ Zoological Survey of India (Western Ghats Regional Center) Kozhikode 673006, Kerala, India

${ }^{2}$ Malabar Natural History Society, B. G. Road, Nadakkavu, Kozhikode 673011, Kerala, India Email: kgemily@gmail.com ${ }^{3}$ 